\title{
Orchestrating children's action: an in-depth multimodal analysis of child-educator interactions in one Italian early childhood education setting
}

\author{
Marilena Fatigante ${ }^{1}$ (D) $\cdot$ Lilia Antici $^{2} \cdot$ Cristina Zucchermaglio $^{1} \cdot$ Valentina Fantasia $^{1} \cdot$ \\ Francesca Alby ${ }^{1}$
}

Received: 14 May 2020 / Revised: 11 February 2021 / Accepted: 18 March 2021 /

Published online: 21 May 2021

(C) The Author(s) 2021

\begin{abstract}
Early childhood educational centers (ECEC) are contexts where young children make their first contact with specific, culturally determined rules, practices, and values. Only a few studies have analyzed in-depth the practices through which the educators direct the children's action and attention while they are performing routine educational activities. By means of detailed transcription of educators-children conversations and Conversation Analytic methodology, this work examines a set of videorecorded interactions collected in one Italian ECE center ("nido"), particularly focusing on the verbal and multimodal resources employed by ECEC teachers as they manage episodes, where the children diverge from an expected course of action. Analyses reveal that the educators employ a variety of multimodal resources to orchestrate the child's attention and actions toward the desired course of activity, which open spaces where the child's agency, however more or less strongly reprimanded, is admitted and negotiated.
\end{abstract}

Keywords Directive sequences · Conversation analysis · Orchestration · Multimodal interactions · ECE center $\cdot$ Italy

Marilena Fatigante

marilena.fatigante@uniroma1.it

Lilia Antici

lilia.antici@gmail.com

Cristina Zucchermaglio

cristina.zucchermaglio@uniroma1.it

Valentina Fantasia

valentina.fantasia@uniroma1.it

Francesca Alby

francesca.alby@uniroma1.it

Extended author information available on the last page of the article 
Early childhood education centers (ECEC), known in Italy as "nidi" (literally, "nests"), are educational contexts devoted to children aged 0-3, organized under the primary goals of providing daily extra-family care and opportunities for socialization. Through their participation in daily activities with peers and educators, young children make their first contact with culturally determined rules, practices, and values (Ben-Ari, 1996; Buchbinder et al., 2006; Catarsi \& Fortunati, 2013; Monaco, 2007; Tobin et al., 1989; White \& Dalli, 2017).

Children's participation in play and learning routines in ECEC has attracted a growing body of research (Bateman, 2015; Howes, 1987, 1988; Kidwell, 2012; Molinari et al., 2017; Musatti \& Panni, 1981; Singer \& de Haan, 2007; Singer et al., 2014; Whitebread, 2012; Whitebread et al., 2012, cf. García-Carrión \& Villardón-Gallego, 2016). However, only a few studies so far have documented in detail what communicative resources ECEC educators use to support and direct children's engagement in daily activities. The present work aims to partially fill this gap, by particularly investigating educators' intervention in directive sequences, i.e., sequences in which the educator attempts to orient the child toward a certain-either explicitly or implicitly expected-course of action. By adopting a video-ethnographic and conversation analytic methodological approach, the study analyses the multimodal and sequential ways by which educators in an Italian ECE Center respond to children's initiatives that diverge from an expected conduct, and how they manage to get the children's compliance and collaboration.

\section{Children and educators in the nidi: a background}

Ethnographic research done on ECEC and kindergartens (Corsaro, 1997; Tobin et al., 1989; cf. also Buchbinder et al., 2006) has indicated early educational contexts as important and rich environments for cultural production and socialization, primarily mediated by social interactions with peers and skillful tutors (Vygotsky, 1978).

In the past few decades, a growing research interest has developed on the best educational practices adopted to stimulate and support children's development of cognitive, social, and emotional competences at ECEC. Besides "structural" variables of the context (such as class size, educator-child ratio, educators' qualifications, material context of the setting), the quality of social interaction between children and educators is indicated as one of the most influential dimension for children's developmental and learning outcomes (cf. Pianta et al., 2005; Smidt \& Lehrl, 2020; Ulferts et al., 2019; White et al., 2015).

Studies often rely on standardized observational instruments for describing and assessing key aspects of educators-children interactions, such as, the ITER (Infant and Toddler Environment Rating Scale-Revised Edition; Harmes et al., 1998; see Bassa Poropat \& Chicco, 2003 for the Italian adaptation SVANI scale), the Caregiver Interaction Scale (CIS; Arnett, 1989), and the Classroom Assessment Scoring System (CLASS; Pianta et al., 2008).

One key aspect described by those instruments is educator's directive approach, or directiveness. Directiveness refers to the adult's behavior aimed at restricting (e.g., via using of commands or questions; Erving Tripp, 1976) the child' initiative, by orienting his or her attention or action toward a particular focus; in most of the cases, directive behaviors involve an expected behavior or response by the child (Girolametto et al., 2000).

In educational settings, a systematic use of directive communication by the teacher has been observed as negatively related to the educators' responsiveness (i.e., the extent to which the educator responds and attends to a child's self-initiated move; cf. among others, Flynn \& 
Masur, 2007) which, in turn, appears to be positively related to children's initiatives and engagement in talk (Mercer \& Howe, 2012; Rojas-Drummond et al., 2013).

Examining children approximately between 2 and 3 years, while they engage in play activities, Singer et al. (2014) highlight how the educators' explicit directives negatively impact on the children's spontaneous course of action by interrupting it or reducing the children's degree of participation in the activity. On the contrary, the physical proximity of the educator with the playing area of the child, and her degree of responsiveness toward a child's initiative, positively correlates with the quality and degree of children's individual involvement in the game.

In another study focusing on peer conflicts in kindergartens, Majorano et al. (2015) observed that the way in which educators intervene in children's disputes (mostly by means of control utterances), impacted children's experience of reaching a shared resolution of the conflict autonomously. In other words, directive strategies may not always be the correct answer to guide children's behaviors. An ethnographic study by Musatti and Mayer (2011) showed how educators' in one Italian ECEC, in engaging with 6 to 28 months infants, avoided verbalized instructions and explicit directive moves to direct the children's attention and action: rather, they used the contextual resources surrounding the children (e.g., the spatial arrangements of objects in different areas of the ECEC site) and their own position and movements throughout the ECEC's space as primary means and help maintain their concentration toward a certain activity (either individually or in group) and limit their diversions from what they currently engage.

Siri Mehus (2011) has described how educators in a specific ECEC community tend to avoid standard directives, whereas they employ a range of multimodal resources (including voice, kinetics, gestures, lexicon) in order to discourage children's engagement toward undesired courses of action or to have them stop a current undesired behavior. These resources range from altering the physical environment of the child's actions to prevent certain actions (doing "anticipatory contextualization") to transforming a uncooperative move of the child into a cooperative one and resolving a problematic episode of non-compliance.

Overall, these studies provide a useful background for the examination of what interventions the educators implement, aimed at directing the children's attention and conduct, particularly when they do not follow an expected course of action or do not comply with (either explicit or implicit) instructions. Nevertheless, there is a substantial lack of studies on directive sequences in ECE centers, particularly, adopting video-based observational methods and an in-depth analysis of children-adults interactions.

Most studies about directives in educational, extra-familial contexts consider verbal instructions, issued in elementary school contexts (e.g., Cekaite, 2015; Dalton-Puffer \& Nikula, 2006; He, 2000; Holmes, 1983; Iedema, 1996; Oliveira, 2009).

The examination of how directive strategies are implemented in ECEC centers can give us particular insights on how educators enact cultural, local perspectives on children's action and initiative in this context, and how they balance between possibly competing socialization goals (Gernhardt et al., 2014), such as leaving children to freely initiate and pursue autonomous courses of action (attitudes, which are seemingly favored by caregivers in western educational contexts; cf. Harkness et al., 2000; Fasulo et al., 2007), and train them in respecting shared rules, embodying the other's perspective, following and trusting the educator's authority. 


\section{Directing children's actions: insights from the family context}

In the context of family environment, a number of studies within the field of Language Socialization (Duranti et al., 2012; Schieffelin \& Ochs, 1984) has dedicated a particular focus on parents-children directive sequences, and to the specific conversational resources by parent and children negotiate that a certain course of action is carried out and certain instructions complied. Focusing on data from "western," middle class, urban, and educated families, these studies have shown how obtaining the child's compliance to a directive is the outcome of a long sequel of efforts and negotiations from both parties, within broader "trajectories" (Aronsson \& Cekaite, 2011; Craven \& Potter, 2010; Fasulo et al., 2007; Galeano \& Fasulo, 2009; Goodwin, 2006; Goodwin \& Cekaite, 2013; Hepburn \& Potter, 2011).

In different sites (Italy, Sweden, and USA), what parents and children build up (sometimes reaching a concerted destination, sometimes not) assume the contours of real choreographies (Goodwin \& Cekaite, 2013, 2014, 2018; Tulbert \& Goodwin, 2011), i.e., sequentially and temporally ordered (Schegloff, 2007) trajectories of actions, realized via several communicative resources. These include varieties of speech acts (Austin, 1962) ranging from invitation, requests, pleas, to commands and threats (Craven \& Potter, 2010; Hepburn \& Potter, 2011); more or less elaborated accounts or normative explanations (cf. Galeano \& Fasulo, 2009; Paugh \& Izquierdo, 2009; Sterponi, 2009); prosodic intensifications and vocal modulators of affect (Pauletto \& Fatigante, 2015; Galeano \& Fasulo, 2009; Goodwin \& Goodwin, 2000), by which parents either affiliate with the child or, display disapproval, often in escalating fashion (Craven \& Potter, 2010; Hepburn \& Potter, 2011); the recall of intergenerational negotiations labeled as "activity contracts" (Aronsson \& Cekaite, 2011), i.e., spoken agreements that allocate duties and moral responsibilities to children for complying with the expected action (of, for resisting to it). Bodily and multimodal resources have an utmost importance in the sequential management and the attainment of the result of a directive sequence: a varied range of embodied actions such as, participants' turning their bodies to look at each other, getting the children to face the parent while the parent is telling them what to do (Goodwin, 2006; Goodwin \& Cekaite, 2013, 2014), tactile resources (Cekaite, 2010, 2015, 2016; Cekaite \& Holm Kvist, 2017; Goodwin, 2017), are finely calibrated (Goodwin \& Cekaite, 2013), in order to establish of "a framework for mutual orientation," which is a pre-requisite for the recipient of a directive to fully understand and respond to it.

Drawing on these studies, our work examines, by qualitative and conversation analytic methodology, a set of children-educators interactions unfolding during the morning schedule of one ECEC activities, which all share the occurrence of children's diversion from an expected course of action. Focusing on such episodes, we analyze the verbal and multimodal resources, which ECEC educators use to manage the children's conduct, and to direct or, redirect children's attention and engagement in the "official" or main course of action, that is momentarily ignored or abandoned.

\section{Method}

\section{Setting}

The study has been conducted in "The little bear," a public, full-time (7.30 am-5 pm) ECEC (a "nido") located in Rome, which hosts children from 3 months to 3 years. Public ECEC in Italy are 
under the jurisdiction of municipalities, and they have a communal organization: the ratio adult/ children is 1:6; children are divided in three different groups/sections, "small" (piccoli), "medium" (medi), and "grownups" (grandi); professionals have varied profiles, accordingly to their age and seniority in the service and they are commonly recruited after having passed a public exam in education; they get regular in-training courses by experts from both academic and professional fields; the most of them have opening hours between 8 a.m. and 4.30 p.m., a few of them offering also their service from 7.30 up to 6.00 p.m.; parents pay accordingly to their income and schedule (for a discussion on Italian ECEC organization, see Musatti \& Picchio, 2010).

"The little bear" shares with all other ECECs belonging to Rome municipality, a pedagogical model called "Orientamenti," elaborated in collaboration with researchers (from the academic fields of education, psychology of education, developmental, and social psychology) and professionals. This manifesto is rooted in well-established pedagogical theories, such as (among others) that of Maria Montessori with its emphasis upon the child's opportunity of autonomous sensory motor exploration of material and space, Piaget theory on cognitive and play development of children 0-3 years old, and socio-constructivist theories such as that of Vygotsky (1978) and Bruner (1990) with their related emphasis on the benefits of children's participation in peer conversation, group play, and discussions. These principles are implicitly embodied in the educators' preference, observed in this ECEC, to pay attention to spaces and times of the children's daily experience, to support children's collaboration, their sense of reciprocity and group belonging, and to solicit them to use language and argumentation in conflict resolution.

\section{Participants}

Four female educators and 12 children consented and participated to the study: of the children, 5 were boys and 7 were girls (aged 2.10 to 3.3 years).

Informed consent, approved by the Departmental Ethical Committee, was gained from the Director of the Local Educational Centers and the ECEC coordinator first, then from educators and children's parents.

\section{Data corpus}

Data include longitudinal ethnographic observations collected in the center over the course of 5 months, and approximately $8 \mathrm{~h}$ of videorecordings of interactions occurring between participating children and their educators, collected at different moments of the morning routines. Ethnographic observations, prior to the collection of videorecordings, provided details about the spaces, timings, and daily routines at the center, with a particular focus on the morning activities. The observations included field notes, as well as a collection of photographs and analysis of written documentation related to the practices of the context (e.g., educational project, official institutional documents, training material available to educators). Ethnographic fieldwork oriented us to select specific moments of the day, as particularly feasible to the collection of videorecordings, namely (1) when children engaged in free play during the morning reception, between 7.30 and 9 am; (2) when children engaged in scheduled laboratory activities (e.g., painting activities, sensorial activities such as the exploration of the sandbox) between 9.30 and $11.00 \mathrm{am}$; (3) when children engaged in spontaneous play activities and peer interactions between 11 and $12 \mathrm{am}$, prior to lunch. Meals, hygiene, and sleep routines were excluded from videorecorded observations due to the need to avoid filming those children, whose parents had not released informed consent, and who would have been 
easily involved with the others in larger groups (e.g., lunch tables) and smaller groups (e.g., groups for going to the bathroom).

\section{Data analysis}

We adopted Conversation Analysis (Goodwin, 1981; Sacks et al., 1974; Schegloff, 2007; Stivers \& Sidnell, 2013) as the primary theoretical and methodological framework to examine transcripts of videorecorded interactions and conduct an in-depth analysis of episodes, where children diverge from an expected course of action, which were the focus of our study.

Conversation Analysis (CA) is a qualitative method, originated in the ethnomethodological field in sociology (Atkinson \& Heritage, 1984; Garfinkel, 1967), that aims at analyzing the meaning of mutual actions maintaining adherence to the participants' points of view, that is, to the ways in which participants at conversation interpreted their and their co-participants' actions. The ethnomethodological and CA principle of "relevance" (Psathas, 1995) commands that the analyst does not appeal to pre-emptive categories commonly used also in standardized instruments to assess interaction (e.g., supportive vs. obtrusive, warm vs cold, responsive vs. detached), considered too holistic and highly dependent upon the researcher's judgment. For CA scholars, the attribution of meaning to any of the participants' action or, turn, either verbal or nonverbal, in a conversation can never be done in isolation from the sequence, which is the sole unit of analysis in this paradigm. Thus, the CA analyst closely follows the turn-by-turn development of actions, constantly checking how each turn is interpreted by participants in light of what precedes it, and how any turn anticipates and constraints the range of relevant actions that can be performed next.

For all these reasons, turns are finely transcribed, accordingly to the Jeffersonian conventions specific of the CA methodology (Sacks et al., 1974), which allow to capture both the sequential placement of participants' turns (whether they come after a pause, in overlap with the prior contribution, latched etc.) and their prosodic contour (e.g., emphasis, voice volume, pitch, inbreath) all elements that are taken as relevant indexes, - available to participants, as well as to the analyst - to interpret what is going on, on a moment-by-moment basis.

As for our purposes and the availability of videorecordings, the transcription of speakers' verbal turns were complemented with the annotation of multimodal aspects of the production of participants' actions and turns (Goodwin, 2000; Depperman, 2013; Mondada, 2016; Streeck et al., 2011), including gaze, gestures, posture, spatial positions of the body among the participants, and manipulations of objects and material context, co-occurring within and between each speech turn. These have been considered as full components of the construction of turns (Ford et al., 1996) and essential carriers of semiotic meaning together with speech resources; in the transcript, they were marked by an asterisk (see Appendix).

Names in the transcripts have been modified into fictional ones. Images were used, when useful to illuminate how participants' actions and gestures were arranged in relation to talk, as to produce a certain outcome. Due to issue of privacy, images were blurred and transformed into drawings in order to avoid participants' facial recognition.

\section{Selection of episodes and analysis}

Within the whole corpus of videorecordings, a subset of activities were identified: namely, those, where the children make visible (1) their non-compliance with the expectations that they 
engage in a certain course of action, one, for which they already know the rules of participation, either because they obtained explicit instructions just prior the beginning of the activity or, because they are already socialized to them as part of the ECEC's life; (2) their disengagement from the main, "official" course of action that is expected, and which they have been carrying on up to now. The authors joined in collective discussion to identify within these episodes, the point in the conversational sequence that made manifest the child's orientation to a competing focus of attention and the educators' interventions to re-engage the child and redirect her/his conduct onto the expected, officially established, activity. Across the $8 \mathrm{~h}$ of video, 12 episodes were identified, which corresponded to the criteria described above.

\section{Results}

We analyze two episodes, which are particularly representative as for the length and variety of strategies that the educators employ in addressing the children and re-orienting their conduct toward the activity that was ignored or abandoned.

Accordingly to CA methodology, analyses targeted how child educator's turns (or, educator- child's turns) unfolded in pairs (adjacency pairs, Schegloff \& Sacks, 1973) and what interactional consequences they produced from the moment in which the child's conduct or disengagement was signaled by participants, to the moment in which either the child complied with the educator's request and/or call for re-orientation to the activity, or the episode moved to an end (e.g., with the child's or the educator's withdrawal).

\section{Analyses}

\section{Orienting the child toward engagement onto an expected activity}

In the first episode, the child' behavior that originates the activity of re-direction is the disguise of an established rule in the ECEC, which forbid children to bring their own toys at the center. The episode occurs during the morning routine of the so-called "Welcoming", i.e., a time, from the opening $(7.30 \mathrm{am})$ to the close of the entry $(9.15 \mathrm{am})$, in which children, as they come to the center, are free to play in the various spaces (each one, arranged for a different activity such as building blocks, pretend play, costumes, vehicles etc.). This routine is useful to allow children, who arrive to the Center at different times, a gradual and smooth familiarization with the spaces, toys, and social environment outside the family.

In one of the ECEC free play spaces, a group of 4 children are sitting on a carpet together with the educator, engaging in a building block activity. Children are allowed to enter the classroom with an object (and/or a pacifier) brought from home, provided that it is put aside as they enter the play area and at the educator's request. This is a well-established rule of the center that ethnographic observations and informal interviews with the educators revealed that children are aware of.

Manolo, a 3 years old child, has a toy car brought from home in one hand, and a pacifier in another. As the episode begins, Manolo has approached the carpet and is standing still, looking the group of children that is sitting on it and playing at building a tower. The educator (Edu1) acknowledges Manolo's presence by slightly turning toward him and keeping observing him (Tables 1, 2, 3, 4, 5, 6, 7, 8). 
Table 1 Excerpt 1a

Participants: Edu 1, Edu 2 (behind the camera), Manolo (3 years), Gioele (3 years), Natalie (3 years), Chiara (2 years and 10 months)

Edu1 is seated on the carpet with her back against the wall, 3 children are on the carpet with her and play with the constructions, Manolo is initially on the left outside the carpet, standing with his car in his hand; Edu1 looks up at Manolo and smiles at him

(6.0) Manolo moves around the carpet towards Edul

(1.0) Edu1 looks at Manolo standing in front of her (with his back to the camera), he looks at her;

(2.5) Edul opens her arms and turns her palms up, as to waiting for something or someone to arrive. Manolo takes a step towards her

(vogliamo) posare qualcosa \$qu*a sul mobile?=

(shall we) put something aw\$ay $u * p$ here on the cabinet?=

$\$$ Manolo moves on sitting within Edul's legs

${ }^{\star}$ Edul bangs her hand twice on to the cabinet

As a matter of fact, by holding the toy car in his hand, Manolo is unable to participate in the group activity. As she looks at Manolo, the educator smiles at him, signaling affiliation and availability to interaction. The movement of the child towards her (line 1), ending as he sits on her legs (line 4), makes manifest his search for proximity with the educator, a search that has, to a certain extent, been solicited by her smiling - and, certainly, that it is welcomed by her, as she opens her arms toward the child at line 3. Yet, Manolo's movement also traces a trajectory, which Corsaro (1997) identified as "encirclement", i.e., a children's strategy to approach the play area (physically circling it) and shows an initial availability to join, without verbally asking or intruding immediately. We cannot make any claim about Manolo's intention to do "the two jobs" with his conduct. Yet, we note an initial ambivalence here, maintained by the evidence that Manolo's circling movement allows him to come closer to the educator, while, at the same time, not lose sight of the play area and the children's building block activity in there. Let us look now at the educator's sequel of interventions. The educator's use of the inclusive plural pronoun "we" (line 4; "shall we put something"; Benveniste, 1966) works as affiliative, persuasive strategy (cf. Ochs \& Schieffelin, 1989), inviting Manolo to abandon the toy he is handling. Concurrently, by verbally indicating ("up here on the cabinet") and physically touching the cabinet, she gives the child clear indication about how to orient his gaze and actions, implicitly asking him to comply with the general rule (i.e., leave aside the toy brought from home).

A difference in intonation between the first invitation (line 4) carried out in ascendant, interrogative tone, and the second assertion (line 5), marked by a falling tone, can be noted, which clearly signal a shift from a request - asking someone to do something - to an imperative - telling someone to do something (cf. Curl \& Drew, 2008). Yet, the plain and soft tone in which the imperative (line 5) is carried out appears to make the turn closer to a description of a current state of affairs. This modifies what could be heard as a educator's command to the 
child, telling him to do what he has not yet accomplished, onto an assertion that anticipates the child's action as an accomplishment the two participants have agreed upon. Both verbal communication and actions mark very punctually the trajectory of action proposed by the educator, dragging the child's attention and conduct toward the target aim and location (Cekaite, 2016; Goodwin \& Cekaite, 2013). However, this multimodal strategy of the educator does not succeed at first attempt, in that the child explicitly refuses to comply (line 6). At present and for the next $3 \mathrm{~s}$, the child has not yet directed his gaze towards the shelf indicated by the educator.

Table 2 Excerpt 1b hands

09 Edul

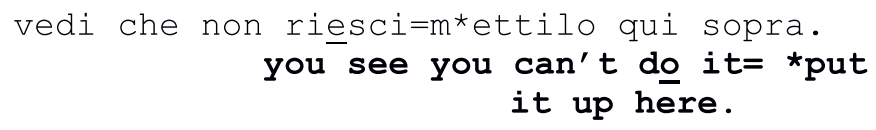

* touching the cabinet

11 Edul q[u个a, h [e个re,

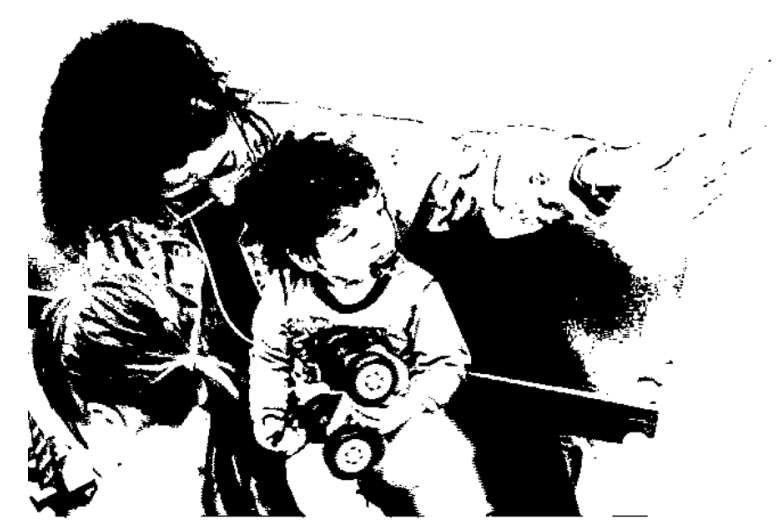

12 Man [gazes away from the cabinet and shakes his head

13 Edul allora non le vuoi fare le costruzioni so you don't want to play with the building blocks

14 Man turns gaze to the right side, where the building blocks are 
Having failed, in the first sequence (Excerpt 1a) to get Manolo place the toy away via simple requests, the educator changes her strategy and proposes to Manolo a testing of the evidence: she asks Manolo to observe ("see," line 9) how the holding of the toy prevents him from successfully perform another activity. She latches this assertion with the directive "put it up here," produced while stretching the arm toward the cabinet. Her move is followed, for the first time, by a visual and prolonged orientation of the child towards the cabinet top (line 10). Relying on this change in the child's orientation, the educator seizes the opportunity to provide an additional specification on the appropriate place to put the car (line 11, see Figure in the transcript), and also, by maintaining her hand on the shelf, she anchors the child' s attention more strongly toward the expected conduct. See that the child sits on the educator's laps, "encircled" by the educator's body. The mutual position they maintain — with the adult positioned behind the child's body-has aspects similar to what Cekaite (2010) calls as $C$ formation, an embodied position of control, but it also indexes intimacy and affect (Cekaite \& Holm Kvist, 2017). Contrary to Cekaite's examples in family directive sequences, though, here the educator does not bodily "steer" the child toward the desired outcome but more discretely orients Manolo's attention in order that he finally accepts to comply.

Despite this new, verbal, and embodied directive, Manolo's answers with a further, open rejection (line 12). This is, though, interpreted by the educator as the child's unwillingness to play the building blocks with the other children (line 13). In doing so, the educator re-contextualizes (Mehus, 2011) the child's action, and, instead of focusing on its meaning as resistance toward her invitation, she shifts to commenting on the child's motivation to join the collective play that is going on the carpet, and that is accessible to the child's gaze. This way, she orients the child's attention toward the group activity, an intervention that is in fact followed by a new redirection of Manolo's gaze toward the carpet again (line 14):

Table 3 Excerpt 1c

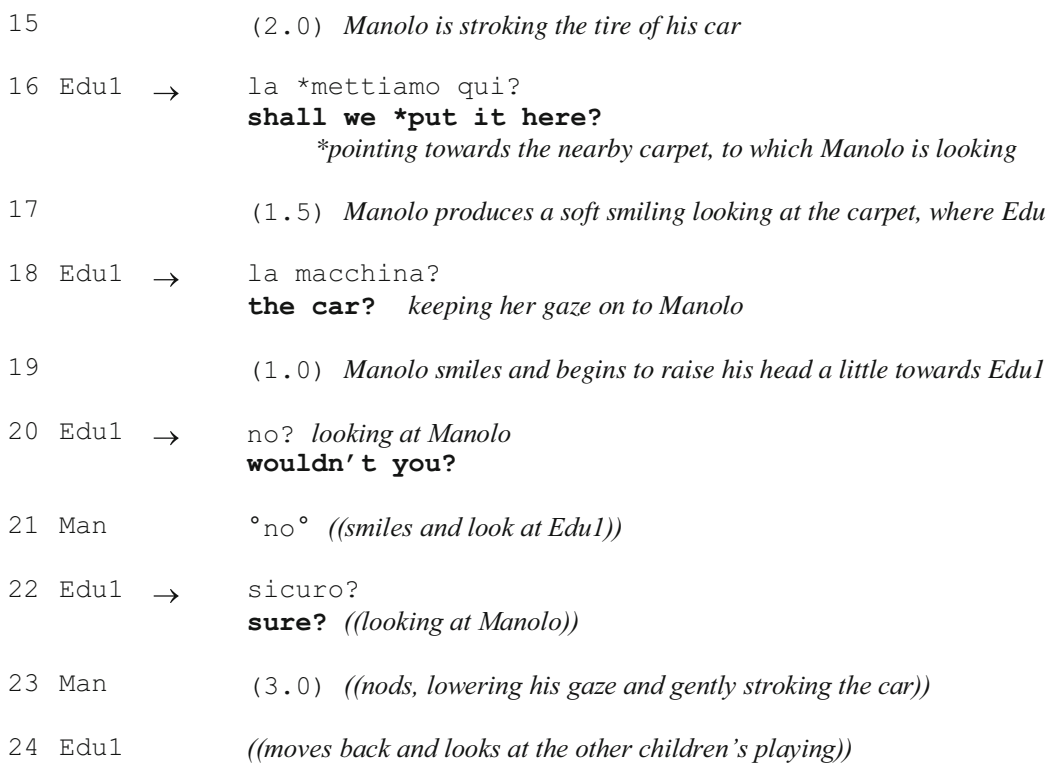


In the sequence developing through lines 15-20 there are four more educator attempts (marked with arrows) to make Manolo abandon his toy, which consist in progressive revisions of her original proposal: one, formulated again in the plural affiliation (line 16), and finally two requests for confirmation (lines 20 and 22). These provide a sequential scaffolding of the child's opportunity to respond to the request, in that they offer Manolo the opportunity to revise his answer in the midst of the course of action he is pursuing (which constitutes in fact an explicit resistance to the educator), and conform to the course of action expected by the educator instead. The educator's repair turn (line 18: "the car?") which clarifies the ambiguous reference "it" contained in the previous turn at line 16, plays an important job: similarly to what happens in the previous Excerpt (line 11), where the indexical gesture to the cabinet showed Manolo the place where the educator was inviting him to put the object away, the naming of the item as "the car" seems to be useful to "anchor" the child's attention toward the material object that needs to be placed away.

These interventions seem to have an important effect when observed in the extended temporality of the sequences we have analyzed. If it is true that Manolo's answers affirm his willingness to not correspond to the educator's request, he shows a gradual proneness to co-orientate and tune in with the educator's requests and invitations as the sequence develops (cf. lines 17, 19, 21). The smiles that accompany, respectively, his resistance to respond and his refusal (lines 19 and 21) of the educator's proposals, seem to betray a progressive conversion of meaning of his actions from that of an overt opposition into a playful activity between him and the educator. The sequence of the different interventions of the educator result in opportunities to shape the child's behavior, allowing him - in a rather extended amount of time (the whole episode lasts $3.30 \mathrm{~min}$ ) - to measure and "navigate" the boundaries of his self-determination as well as the adult's tolerance towards it.

An additional important feature of the overall educational strategy implemented by the educator is giving the child "his time." With this strategy, the educator's interventions achieve a relevant goal in the socialization of young children in ECEC: to support the child's participation in group activities (Singer et al., 2014), and socialize him to respect the rules apprehended in the center. The last two sequences of the episode clearly describe this (Excerpt 1d).

The strategy adopted here by the educator is built up in three steps: first, she formulates an initial open request, asking Manolo a question, (line 25: You don't want to do anything today?), which ascribes him a willingness and agency to refrain from engaging in any activity during the day. On the other hand, the question (and the request for confirmation formulated later) attributes to the child the opportunity to formulate a desire (cf. the selection of the verb "want") of an alternative plan of action with respect to being (or not) involved in the group play situation. Secondly, as she obtains an answer from Manolo, who in fact confirms the desire to "do nothing," she acknowledges the child's response ("alright"), thus apparently withdrawing from pursuing the child's compliance. Yet, she continues and formulates another question to Manolo, which reinterprets the child's choice to not be involved as a meaningful action which can be carried out by both, i.e., a shared activity of observation of the other kids: these are labeled as "little friends" (line 29) as to rhetorically build a sense of intimacy between Manolo and his peers, useful, in turn, to cast Manolo's status as a member of the group he is resisting to join. Third, the educator finally reiterates the 
Table 4 Excerpt 1d

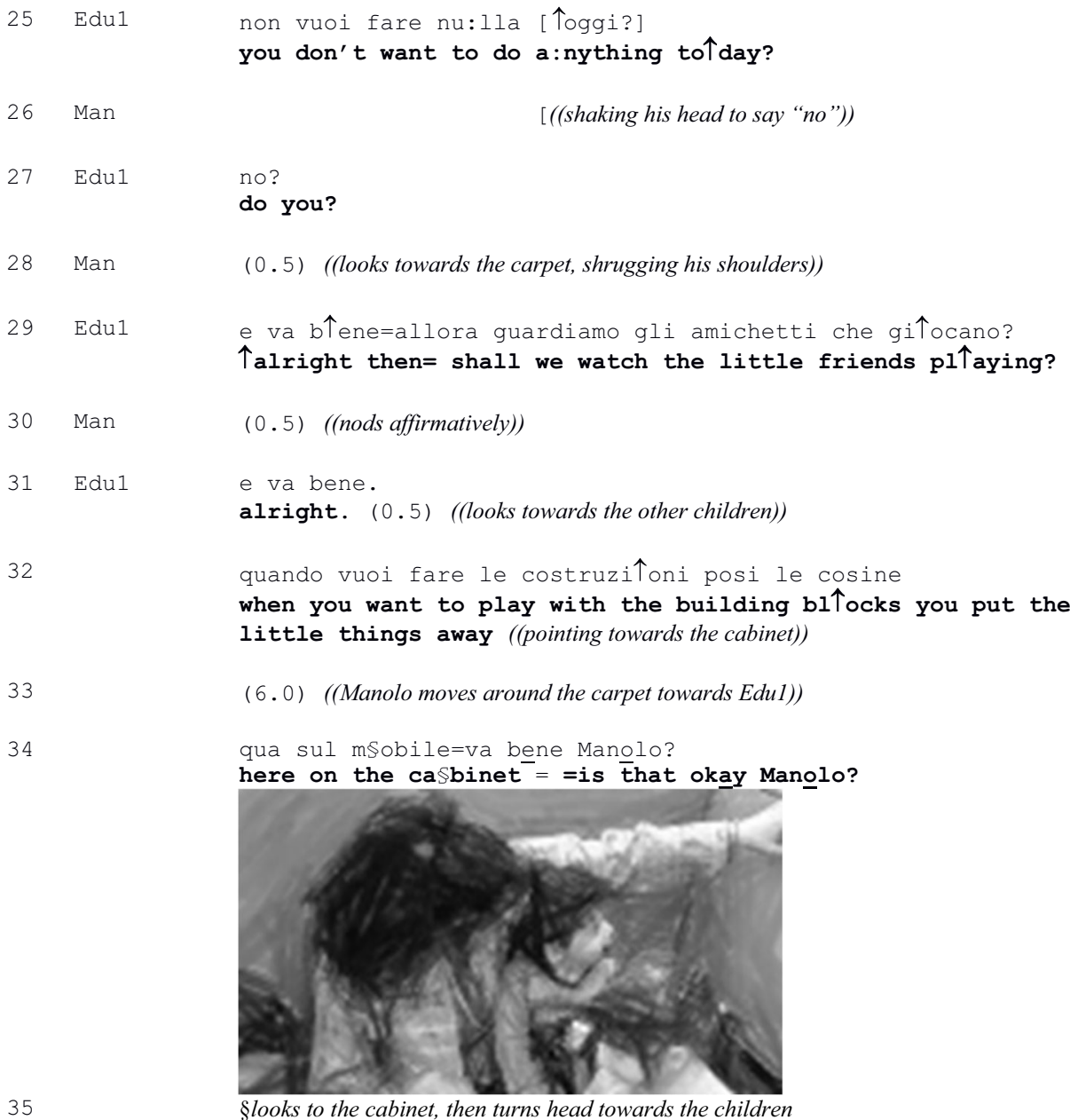

directive for the child to place the toy on the cabinet explicitly (lines 32-34); in doing so, she adopts a syntactic construction, which projects the child's agency in a future and anticipated scenario (line 32) assuming that the child will be willing to get involved in the shared activity at some point. In this way, she conveys that she trusts that the child will eventually show his orientation to engage with the other peers in the shared activity. Through her verbal interventions, body positioning, gazes, and pointing gestures, the educator provides Manolo a "model for action" and patiently guide and monitor, through an extended span of time, the child's compliance. A few minutes later, Manolo shows his orientation to engage in the other children's activity nearby (Excerpt 1e).

In the Excerpt 1e above, as the educator makes a further invitation to Manolo to engage in the building block activity, the child signals quite clearly - through his posture and gaze 
orientation - his reluctancy (and then refusal) to join in. While the silence (of $2 \mathrm{~s}$, line 38) and the following shrugging gesture mark a mismatch between the educator's request and the child's initiative, they also suggest a decrease in determination ("dunno", line 41) with which, previously, the child had made a clear refusal to the proposal. Various educator's encouraging actions follow, displayed first in her attempt to make the construction activity attractive through a positive evaluation (line 39), and through an explicit invitation to Manolo to make his own building (line 40). At line 42, the educator's problematizes the child's response "boh" (meaning, don't know), and constrain his response to a yes/no answer (line 43). Again, however the child is apparently left freedom, and an equal chance to respond yes or no to the educator's invitation, the "no" response is in fact cast as inappropriate and rejected.

Table 5 Excerpt 1e

36

$37 \quad$ Edu1

38

$39 \quad$ Edu1

40

$41 \quad$ Man

$42 \quad$ Edu1

$44 \quad$ Man

45 Edul $\rightarrow$
((Manolo stares still to the other children's playing))

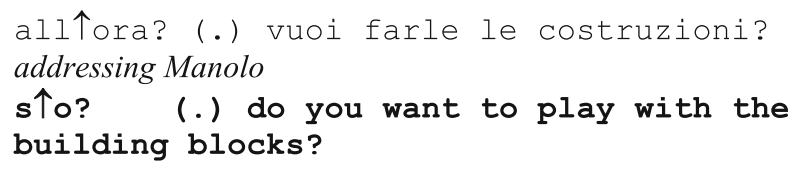

(2.0) ((Manolo looks at the children then shrugs))

gua个rda che costruzioni belle che *stanno facendo Natalie e Gioele:

lo个ok at those beautiful buildings that *Natalie and Gioele are doing

* pointing towards the children and then looking at Manolo

(0.2) ne vuoi fa:re una anche tu::?

would you like to mäke one yourse: :lf?

${ }^{\circ}$ boh: ${ }^{\circ}$

${ }^{\circ}$ dunno: ${ }^{\circ}$ ((shrugging))

c个ome boh?

wh个at dunno? ((looks up and then back to him))

$(0.8)$ o s个i o no,

(0.8) either $y \uparrow e s$ or no,

no ((smiling and looking at the camera))

e da::i: (.) un pochi:no:?

come $0:: n:$ (.) just $\bar{a}$ lí $t$ tle bi:t? 
The educator formulates in fact a marker, used as a prompt for action ("dai", come on, line 45), and as a persuasive device, which has been shown as effective in preventing the use of more direct and imperative forms (Pauletto \& Fatigante, 2015). The interactive complexity and articulation, even temporal, of the sequence of interventions by the educator (turns 40-45) can be interpreted as not only aimed, locally, at obtaining that the child corresponds to the adult's contingent request, but, also, as a more general socialization practice aimed at molding the intentionality of the child (cf. Kochanska et al., 2005) and supporting his engagement toward the desired course of action.

In the following fragment, the last one, we notice a change in Manolo's compliance to the educator's request.

At this point, Manolo gets closer to the building blocks tower, joining in the other children.

In this last sequence here, it becomes more evident how the educator crafts the opportunity that the child complies with her request ("then place the toys up here," line 47) as a necessary condition for his engagement in the shared play with the other children. Insofar as the provision of the directive move is "prepared" by a question, which appears (in that it is not clear in the transcript) to ask the child whether he wants to do a tower, the ensuing imperative (line 47) can be read more as a suggestion for the child to remove the impediment that would prevent his willingly engagement in doing the building blocks with peers. This way, the appeal to authority embedded in the use of the imperative is modulated by the educator's (be it fictional or not) consideration of the child's wish. Indeed, Manolo gets up and leave the toy on the cabinet indicated by the educator several times as the right place for it. Immediately afterwards, Manolo looks in the direction of Edu1 (see figure line 49), a well-established social referencing behavior (Feinman, 1982) accounting for his seeking confirmation and approval by the educator (line 51).

This excerpt has, thus, shown how the "directive trajectory" (Goodwin, 2006) toward the desired outcome involved a complex and temporally coordinated interrelation of the verbal and multimodal resources consisting in (1) different types of verbal initiatives (commands, requests, yes/no questions, confirmation check), (2) use of body actions (e.g., pointing, touching), (3) use and contextualization of the material surroundings (indication of the cabinet, the carpet, the toy/s), and (4) use and contextualization of different participant frameworks and concurrent activities (i.e., the shift to the larger multiparty framework of the children's play on the carpet).

All these resources worked to circumvent Manolo's resistance and gradually strengthen his affiliation with the "communicative project" of the educator (Goodwin, 2006), guiding him to comply to both the expected courses of action: on the one hand, to leave the toy as the ECEC norm requires as an entry rule in the center, and, on the other, to join a play activity with the other children, accordingly to the preferred form of participation that this ECEC, inspired by socio-constructivist and sociocultural paradigm, expects from children.

\section{Breaks in engagements and re-orienting the child}

The next example shows a case in which a girl manifests the attempt to break her current engagement in the main learning activity that has been planned and is currently monitored by the educators. The episode takes place within a joint activity of paper painting, engaged by a small group of children in the afternoon schedule. Natalie, a 3-year-old girl, is seated at the table with three other children. Suddenly, Natalie makes visible her initiative to color her own hand instead of painting on the paper, breaking the course of action that is expected at the 
Table 6 Excerpt $1 \mathrm{f}$

45 Edu 1

46 Man

47

48

49 (a: : lta?)

(ta: : 11)? ((addressing Manolo, probably referring to building blocks tower made by the other children))

(0.8) ((nods affirmatively, looking down))
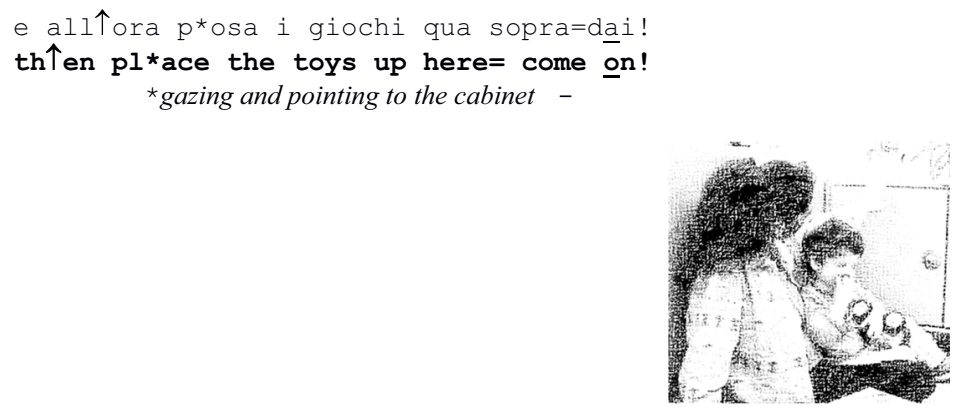

(4.0) Manolo stands up and put the toy care on the cabinet
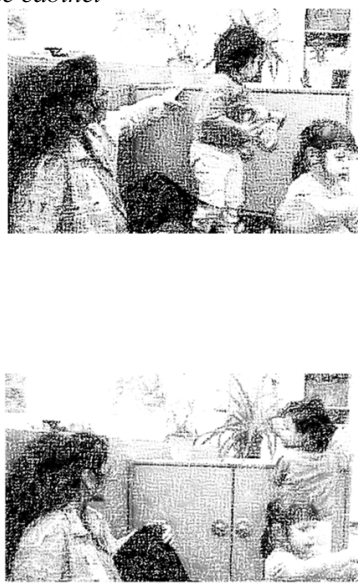

moment, and that has been explained at the beginning (lines not shown). Worth noting, the same group of children had practiced an activity of painting on the hands the day before; therefore, Natalie's deviation from the current task (painting on the paper) might stem from her recalling of the hand painting activity experienced just the day before.

The episode begins as Natalie abruptly raises her hand action, uttering "the hand" (line 1), while turning to Edu1, and soon manifesting her intention to paint her hand. With this combined set of resources, Natalie openly announces her intention to paint her hand, soliciting Edu1's response. Both educators strongly signal the inopportunity of the action projected by the girl (lines 2-3), and Edu1 intervenes directly with a haptic gesture (Cekaite, 2010; Goodwin \& Cekaite 2013) that physically moves Natalie's hand away (line 3) and prevents her to continue in her projected plan. As she stops the child's 
Table 7 Excerpt 2a

Participants: Edu1, Edu2, Nat(alie, 3 years), Mic(hele, 2 years and 11 months), Chi(ara, 2 years and 10 months), Fab(rizio, 2 years and 10 months).
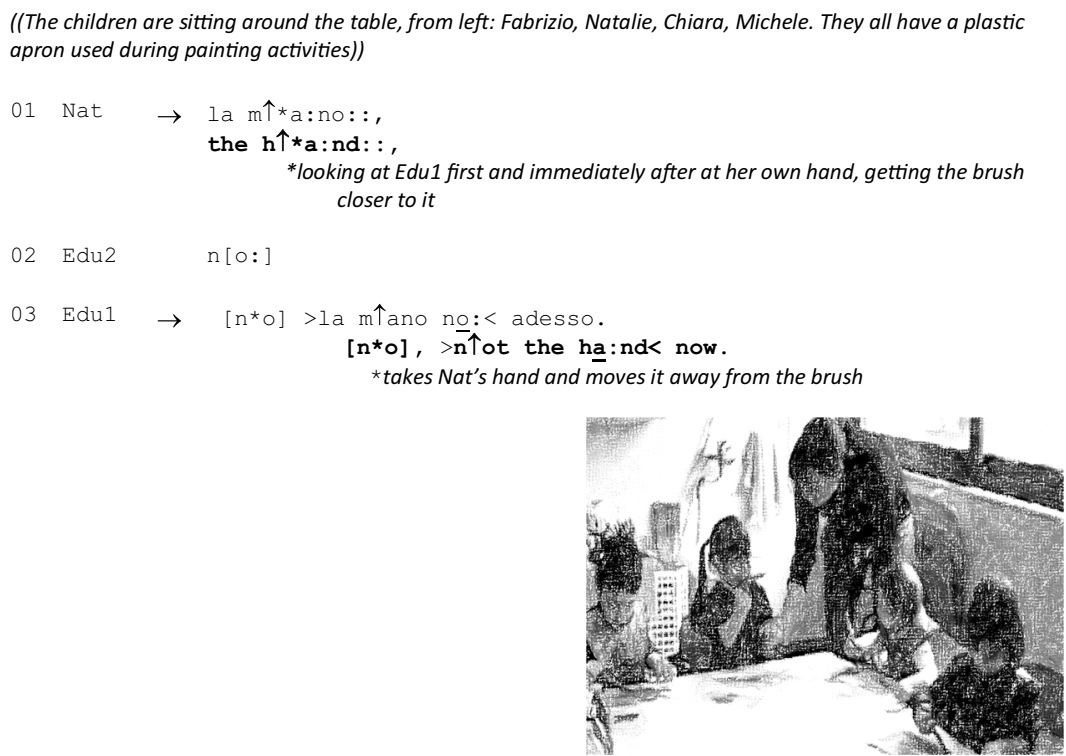

04 Edu1 = d*aii l'hai fatta ieri con la mano.

behavior, the educator justifies her prohibition providing verbal evidence that the little girl herself can consider: hand-coloring was the activity of the previous day, and it is not relevant in the current activity. This call is preceded here by the "dai" ("come on") marker, which works as a modulator of the command in request or prayer, thus strengthening a persuasive job (Pauletto \& Fatigante, 2015). Note that, after having halted the girl's gesture, the educator arranges the paper in front of her so to make it closer to her body (and sight): in C. Goodwin's terms (Goodwin, 2000) the educator contextualizes some properties of the space, in order to increase the girl's access to the relevant perceptual field she is requested to act upon.

This move is followed by the educator's second imperative that makes the expected conduct explicit: "come on paint as usual - with the brush" (lines 5 and 7). Anticipating the issue of the directive, the educator's arrangement and manipulation of the space and materials implicitly orient the girl's actions toward the desired course of action, the recovery of the paper painting.

In a similar vein, the educator in Excerpt 1 configured the relevant space for Manolo's action and attention, by her pointing gestures to the cabinet (Excerpts 1a, 1b, 1d) or the play carpet (line 39, Excerpt 1e). Space, then, is treated as a "material anchor" for the flow of children's attention (Tulbert \& Goodwin, 2011) and acting upon it fully partakes of the directive trajectory in these episodes. 
Table 7 (continued)

$=c^{*}$ ome on you made it yesterday with the hand

* $\bar{b}$ rings Nat's hand on the table and draws the painting paper closer to the girl's body

05 Edul dai pitt $\uparrow$ ura normale.

come on p个aint as usual.

06 (0.4) looks at her own hand ${ }^{\circ}$ (nel10) ${ }^{\circ}($ (= "nello" stands for "pennello", Italian word for brush"))

07 Edul col pennello.

with the brush.

(1.0) ((Nat hangs the brush, slightly shaking it, and keeps the other hand open looking at it; Edu 1 keeps both hands on the table, monitoring her))

09 Edul vuoi

do you wish ((pointing towards a certain place on Nat's paper))

10 Nat

(. ) ((shaking head quickly))

11 Edul (ma) tu volevi il viola?

maybe it's the violet you wanted? ((bending toward Natalie))

12 Mic gua:rda:

loo: $\mathrm{k}$ : ((looking at his hand))

13

$(0.5)$

14 Edu1

$>$ (ma lei il

$>$ (but she (

)

) ((raising her gaze to Edu2))

SNatalie rubs the brush on her hand

\$ $\quad$ ) - e $\uparrow$ NO: $\uparrow \mathrm{NO}:$ [no= no,

Soh $\uparrow$ NO: $\uparrow \mathrm{NO}:$ [no= no, ((to Natalie))

17 Edu1

* [n个o con la mano ( $\uparrow$ chicca:)

* [n $\uparrow$ ot by the hand ( $\uparrow$ sweetie)

* Edu1 holds Nat by the hand, turns her palm down on the table and

presses it

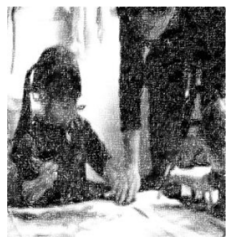

(poi gli ho dato un colore 个solo perché senno' lo vole§vano pure (gli altri)

then I gave her a paint $\uparrow$ only because others \$would ask for one too

$\$$ Natalie raises the hand with the brush pointing it towards herself. Edul steps away from the table, standing close to it

towards her

$\S$ Natalie looks up to Edu1, then looks at her hand with the brush oriented 
Despite the explicit instruction and the implicit guidance offered by the spatial contextualization by the educator, Natalie does not immediately comply with the command: from lines 6 to 8, we see her keeping her gestures still, her gaze on one hand opened, while she slightly shakes the other, that with the brush, as if preparing for a retrieval of the initiative. At line 9, the educator asks Natalie about her color preference. This suspends for a while the sequence of the educator's directive moves addressed to Natalie to make her properly perform her task. The color question introduces two changes in the participation framework: first, it introduces a new topic (the choice of color) and secondly, addressing a request to Natalie, it opens the space for the child to express her desires and preferences, although upon an ancillary element with regard the central focus of the activity. As Edu 1 shifts her gaze from Natalie to her colleague, and initiates a brief exchange with her, Natalie shows a second attempt to color her hand (line 15). This is captured again by Edu2, who utters, in the midst of her turn, an open disapproval of the child's action (line 16), with an aggravated affect intensity as compared to the earlier opposition at line 2. Edu1's turn follows (line 17), which gives the child more explicit instructions about what aspect of the action is discouraged: not by the hand. This command is uttered in a much less reduced volume and pitch as compared to that of her colleague, and complemented by the endearment term "sweetie." As Pauletto et al.'s (2017) have shown in family interactions, when used in turn-final position, endearment terms work as persuasive resources orienting and scaffolding the child's action toward an expected/required outcome.

Both these resources in Edu1's turn work, then, as to mitigate the negative affect embedded in the Edu2's disapproval "no." Concurrently though, Edu1 (line 17) twists the child's hand and pushes it over the table, thus strongly constraining her in the mobility of that body part (Cekaite, 2010). From the video, we note that Edu1's action consists in fact of three parts: she twists Natalie's hand, she pushes it on the table and then gently presses it before leaving it again. This physically halts the child's action from redoing the move. Also, it is the conclusive move of this second "round" of directive sequence, as marked by Edul's action of stepping away.

Not anymore in the spotlight of the educators' sight, Natalie is left to act undisturbed for a while, as the educators engage in interaction with each other and (lines not reported in the transcript) with the other children. After about $50 \mathrm{~s}$ while she is attending to another child, Edu1 "notices" Natalie's action again.

This time the educator's intervention is configured as a reference to the previous "contract" between her and Natalie ("we had said no the little hand, we had said to use the brush, lines 21-22; Aronsson \& Cekaite, 2011). This makes the prohibition to proceed, for Natalie, sustained by arguments and "evidence," recalled as the plan the educator says that they had previously agreed. The wording is accompanied first by a diminutive (line 21), a marker of affiliation (Ochs \& Schieffelin, 1989; Ochs et al., 1996; Pauletto et al., 2017), and then by a praying gesture (hands folded, line 22), which has the function of qualifying what was previously formulated as an external imposition ("no", "do not/do not do"), as a request. See also, that at this point Natalie is not looking at Edul (line 23) nor, she produces any uptake to her call. This is not marked at all by the educator, who, instead, moves to get a new paint (line 24). It looks like the educator, despite her uttered reproach, allows in fact the child to pursue a competitive plan.

At line 25, she asks about the child's preference of getting a new paint, again (as in line 11 Excerpt 2a) opening up a course of action, that creates a diversion from the problematic 
Table 8 Excerpt $2 b$

21 Edu 1

22

25 Edu 1

26 Nat

27 Edu 1

28

29 Edu 1

30

31

32

33

34
N个atalie a (veva)mo detto $\mathrm{n} \uparrow$ : la manina!

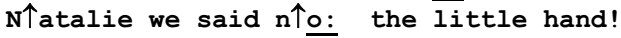

avevamo detto di farla col penn个e:llo:

we said to use the br个u:sh: ((with folded hands))

((Natalie carries on with her activity, following Edu2 with her gaze))

((Edu1 goes and takes a pink painting bottle $))$

vuoi un po' di questo n个atalie?

would you like some of this N个atalie? ((getting closer to her $)$ )

[((gazes up to Edu1))

[però $\mathrm{n} \uparrow$ o sulla mano=

$\mathrm{n} \uparrow$ ot on the hand though

=b个asta la mano.

$=\mathrm{n} \uparrow$ o more with the hand.

(0.4) ((takes Nat's hand and turns it on to the paper $))$

Tora fai la man个ina una volta,

个now you make your $1 \uparrow i t t l e \bar{e}$ hand one time,

(3.0) ((Edul presses Nat's hand on the paper $))$

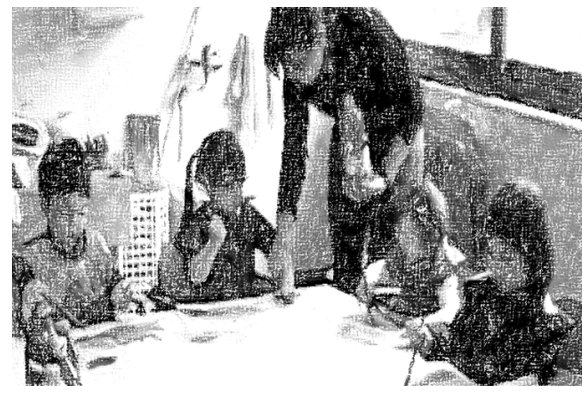

e que $\uparrow$ sto lo fai col penne:llo=

and you do $\uparrow$ th$^{\star}$ is one with the brux:sh=

*indicating a part of the paper

$=\mathrm{va} \mathrm{b} \uparrow$ ene?

$=o k \uparrow a y$ ?

((Natalie looks on the paper and she cleans her hand over her apron))

sequence and obtains that Natalie raises her gaze toward her. At line 27, the educator expresses again the prohibition in the imperative form and definitively commands that Natalie stop hand brushing ("no more with the hand," line 28). Edu1 goes further and enforces her verbal instruction by intervening physically on the action of the girl: she takes her hand (breaking its contact with the brush) and turns it toward the paper (figure, line 31). This way, the educator 
redirects the child's attention to the activity in progress and avoids further deviations from the expected course of action and participation. At that point, she utters a directive that, rather than proposing a simple prohibition, restrictive of the child's conduct, sounds like (given also the affiliative intonational contour) an instruction on how to go on with the action in progress (cf. on this Galeano \& Fasulo, 2009; Kent, 2011).

The apparently "authoritative" gesture, coupled with the verbal instruction, and continuing at line 31 with her pressing of the child's hand, provides the child with an embodied "mold," which brings her original activity (i.e., the hand painting, antagonist with the official one), to an end, while making it meaningful (she obtains that the child makes a handprint on the paper). The educator's gesture works as a closing move for the whole directive sequence, which can open the way to the reinstantiation of the normative course of action (drawing with the brush, line 32), to which the child is instructed to comply.

We also observed that the educator never refers to herself as the source of the command, prohibition or critique. Rather, she invokes a collective agent ("shall we," "we said"), which can be interpreted as marking inclusively also the child as a partner in the accomplishment of the action that was intended as the official one.

As the previous episode, episode 2 just shown offers another demonstration of how directive sequences in this ECEC evolve through an elaborated choreography (Aronsson, 1998; Aronsson \& Cekaite, 2011; Tulbert \& Goodwin, 2011) made of different rounds, and how they involve a varied set of verbal and multimodal resources: these include, here again, (1) a differentiation in types and illocutionary strength of directives (the educator shifts from a prohibition, to command, to requests and prayers); (2) body displays and movements (tactile interventions on the child's body such as touching and pressing); (3) contextualization of the material setting (here, the shifting and rearrangement of the paper and the brush in front of the girl, the offer of the colors etc.); (4) the management of sequential derailments and related variations in participant frameworks, used as strategic route to obtain a shift in the child's attentional focus.

Considered altogether, the two examples show how the educators balance the socialization goal to let the children experience and test, on their own, the potentials and limits of their initiatives, and the socialization goal to drive the children toward adhering to those communal and institutional rules, conducts, and values that are particularly encouraged in this educational setting. In both the two episodes, while the children protagonists (Manolo and Natalie) are more or less explicitly, and more or less strongly contested for, respectively, dismissing or breaking a rule, and while they are instructed to cease their divergent conduct, the educators allocate quite enough time and repeated chances for children to "hover" in the competing course of action they have undertaken.

At the same time, they arrange and test creative solutions for motivating children to engage or (re-) orient toward the expected course of conduct. This conveys a perspective on educational practice, which favors the negotiation of meanings between children and educators, and prioritizes (over the prospect that the educator re-directs the small child's conduct straightforwardly) the opportunity that they build a practical (i.e., meant to accomplish a result) and relational contract, maintaining mutual affiliation.

\section{Discussion}

As first sites of secondary socialization, the ECEC are culturally rich and complex environments, where children learn and train to participate in social interactions with significant caregivers and peers, accordingly to shared rules and expectations. Educators-children 
interactions are informed by, and, in turn, mirror diverse representations of childhood, education, adult responsibility, but are also shaped by the ways in which educators value language, social interaction, and the activities that can be performed by means of language (Tobin et al., 1989).

Adopting a conversation analytic approach, a method that enables the in-depth description of the sequential development of turns and actions, and relying on studies in Language Socialization (Ochs \& Schieffelin, 1989), this paper has shown how educators orient children toward a certain desired conduct, by means of highly coordinated verbal and multimodal directive moves over the conversational sequence.

The fine-grained analysis of participants' turns and actions has shown the work of constant and progressive negotiations that the educators engage with the children, which developed through a considerable amount of time and repeated rounds of directive sequences.

From our observations, two general aspects have emerged as important contribution to broaden our understanding of the strategies with which educators guide and direct the participation of children in educational activities:

1) The preference for the educator to not simplistically reprimand the children and halt their behavior, while, instead, accounting for the directive and scaffolding the children toward the accomplishment of the desired behavior

2) The fine coordination of the educators' verbal and multimodal resources arranged stepwise, sequentially, in ways that give the children time and opportunities to exert their agency in the accomplishment of the action, even allowing them chances to temporarily deviate from it.

These resources, we have seen, span from (1) well-documented verbal and paraverbal resources used in directives to shape the child's compliance, such as: varying the degree of "entitlement" or "contingency" (Craven \& Potter, 2010) conveyed by the design of the directive move (replacing an imperative with a request or viceversa; cf. also Erving Tripp, 1976), accounting and giving the children reasons for the directive (Galeano \& Fasulo, 2009; Aronsson \& Cekaite, 2011), using mitigation resources (e.g., plural forms, endearment terms, diminutives, positive affect intonation; cf. Ochs \& Schieffelin, 1989; Pauletto et al., 2017) to build affiliation with the children and project their compliance as a shared desirable outcome; (2) bodily resources such as gestures, movements of the material available in the space, body movements across the space and in relation to the co-participants' bodies (Cekaite, 2010; Tulbert \& Goodwin, 2011); (3) manipulation of the "architecture" of the conversational exchange, such as topical and sequential derailment, which allows children and educators' momentary exits from the problematic attentional focus of the episode (Mehus, 2011).

Combining language socialization studies with CA informed analyses, our work contributes to the field of studies about "social choreography" (Aronsson, 1998; Goodwin, 2006; Goodwin \& Cekaite, 2018; Tulbert \& Goodwin, 2011) in adultchildren interactions, showing similarities and differences in the ways educators-as compared to parents-intervene to direct the child's behavior. Similarly to what parents do in directive-response sequences with their children, we found how multimodal resources play an essential part in curtailing the children's resistance and molding their conduct in relation to the activity officially planned by the educator 
(Aronsson \& Cekaite, 2011). We have seen that, in order to get the child re-orient to the main, official activity, the educators position themselves physically in the child's attentional (visual and auditory) space (Goodwin, 2006; Tulbert \& Goodwin, 2011) and always accompany the words with a tactile gesture of re-direction of the child's action (Cekaite, 2010). Also, they act upon the child's body and/or material s/he is engaged in order to make relevant certain courses of action, inviting a change either in gaze behavior or object manipulation. Particularly notable is how the choreographic arrangement of these multiple resources helps the educator to both constrain the children's body and action (restricting them from deviation from the desired course of the activity), and scaffold appropriate actions (fostering them to fulfil the desired course of the activity). By means of these strategies, the educators obtain that the child is not unilaterally led to comply but encouraged to personally and bodily engage in the activity, cast as a shared accomplishment (Galeano \& Fasulo, 2009).

We have shown that the educator-child directive sequences ultimately and more or less explicitly host tolerance of the child's resistance, and especially, they open space for alternative courses of action as a way to let the child abandon the "resistant" and problematic conduct, while keeping their attention close enough with the ongoing action.

By these finely coordinated moves, educators work two jobs: dragging the child to comply to a planned activity, while also accommodating — at least partially — the children's alternative plans and leave them the chance to exert their agency in pursuing the course of action they initiated.

By changing and putting in place several adjustments to their directive moves the educators build, in Reddy et al.'s formulation (Reddy et al., 2013: 1760), a "genuine response space" within which the child can incrementally learn how to adjust to the educator's varied solicitations. This is also in line with what Mehus (2011) underlines, by discussing that caregivers, in similar educational contexts, consider the children's "intentions" open to manipulation, and they work to create "an interactional context that is most likely to occasion a desired response" (Mehus, 2011, p. 133). In turn, socialization at ECE centers improve young children's awareness that both behavioral trajectories ("recognizable courses of action," Lerner \& Zimmerman, 2003; Lerner et al., 2011) and their effects are mobile and can be varied moment to moment, enhancing their understanding that both theirs and others' perspective are also open to change.

The analysis of the complexity and redundancy of these episodes solicit us to rethink the construal of non-compliance and consider the directive sequences embodied by these educators as episodes, where the child's participation and agency is recognized, responded to and negotiated (Sairanen et al., 2020).

Limitations of the study rely in the small data sample, the recruitment of a few numbers of educators and children and the selection of one educational site, which make the findings only applicable to this local setting, and possibly sensitive to the interactive styles of the single participants.

However, revealing - via the rigorous, fine-grained Conversation Analytic examination of the video-recordings of interactions - the width, complexity, and variety of the strategies used by the educators in this setting to direct children's action and attention, the study attests the importance of acknowledging the educators' interactional 
competence-including a constant decision-making on how to respond to a child's initiative (Sairanen et al., 2020) — as an integral part of their professional practice.

This brings implications for practice and training of educators, by soliciting researchers and stakeholders in early child education to implement the design and dissemination of observational studies in ECE centers, as well as, to use videobased observations and detailed analyses of interaction, for training and the enhancement of the educators' reflexive practice.

Finally, we maintain that the individual educators' strategies that we have documented in this study may shed light into the collective, institutional environment, which constitute not the personal but, rather, the socio-cultural equipment of the educational community observed in this context.

Further studies are required, to enlarge the analyses conducted in a small sample and complement the qualitative observations of the natural interactions in the ECEC with interviews with educators, in order to better explore the link between the educator's folk and professional representations of the children's competences, and the way they implement these in their routine practices.

\section{APPENDIX}

\section{TRANSCRIPTION SYMBOLS}

\begin{tabular}{|c|c|}
\hline & Adapted from Jefferson 2004 \\
\hline : & Extended or stretched sound \\
\hline $\begin{array}{l}\text { (Underlining of } \\
\text { characters) }\end{array}$ & Vocalic emphasis \\
\hline (.) & Brief pause of less than $(0.2)$ \\
\hline (1.2) & $\begin{array}{l}\text { Intervals occurring within and between same or different speaker's utterances in tenths } \\
\text { of seconds }\end{array}$ \\
\hline (()) & Contextual information \\
\hline (don’t/won't) & Transcriptionist doubt (best guess) or (guess/other guess) \\
\hline . & Falling vocal pitch \\
\hline$?$ & Rising vocal pitch \\
\hline ! & Animated speech tone \\
\hline WORD & Extreme loudness compared to surrounding talk \\
\hline$\circ \circ$ & A passage of talk noticeably softer than surrounding talk \\
\hline[ & Marks the beginning point at which current talk is overlapped by other talk \\
\hline$*$ & $\begin{array}{l}\text { Annotation of multimodal aspects (such as, gaze) enacted by the speaker, co-occurring } \\
\text { with the speaker's words }\end{array}$ \\
\hline$\S$ & $\begin{array}{l}\text { Annotation of multimodal aspects (such as, gaze) enacted by the addressee, } \\
\text { co-occurring with the speaker's words or actions }\end{array}$ \\
\hline$\downarrow \uparrow$ & Marked rising and falling shifts in intonation \\
\hline$=$ & Latching of contiguous utterances, with no interval or overlap \\
\hline$><$ & $\begin{array}{l}\text { Portions of an utterance delivered at a pace noticeably quicker }(><) \text { or slower }(<>) \\
\text { than surrounding talk }\end{array}$ \\
\hline- & Halting, abrupt cut off of sound or word \\
\hline hhh: & Audible inbreaths \\
\hline hh: $\quad$ & Audible outbreaths from such events as laughter, or sigh \\
\hline wo(h)rd(h) & Outhbreaths within words \\
\hline
\end{tabular}


Funding Open access funding provided by Università degli Studi di Roma La Sapienza within the CRUICARE Agreement.

Open Access This article is licensed under a Creative Commons Attribution 4.0 International License, which permits use, sharing, adaptation, distribution and reproduction in any medium or format, as long as you give appropriate credit to the original author(s) and the source, provide a link to the Creative Commons licence, and indicate if changes were made. The images or other third party material in this article are included in the article's Creative Commons licence, unless indicated otherwise in a credit line to the material. If material is not included in the article's Creative Commons licence and your intended use is not permitted by statutory regulation or exceeds the permitted use, you will need to obtain permission directly from the copyright holder. To view a copy of this licence, visit http://creativecommons.org/licenses/by/4.0/.

\section{References}

Arnett, J. (1989). Caregivers in day-care centers: Does training matter? Journal of Applied Developmental Psychology., 10(4), 541-552. https://doi.org/10.1016/0193-3973(89)90026-9.

Aronsson, K. (1998). Identity-in-interaction and social choreography. Research on Language and Social Interaction, 31, 75-89.

Aronsson, K., \& Cekaite, A. (2011). Activity contracts and directives in everyday family politics. Discourse \& Society, 22, 137-154.

Atkinson, J. M., \& Heritage, J. (1984). Structures of social action: Studies in conversation analysis. Cambridge: Cambridge University Press.

Austin, J. (1962). How to do things with words. Oxford: Clarendon Press.

Bassa Poropat, M. T., \& Chicco, L. (2003). Percorsi formativi nella valutazione della qualità [Educational paths in the quality assessment]. Bergamo, Italy: Edizioni Junior.

Bateman, A. (2015). Conversation analysis and early childhood education. The Co-Production of Knowledge and Relationships. Routledge.

Ben-Ari, E. (1996). From mothering to othering: Organization, culture, and nap time in a Japanese day-care center. Ethos, 24(1), 136-164.

Benveniste, E. (1966). De la subjectivité dans le langage La nature des pronomes. In E. Benveniste (Ed.), Problèmes de linguistique générale (pp. 258-266). Paris: Gallimard.

Bruner, J. (1990). Acts of meaning. Oxford: Oxford University Press.

Buchbinder, M., Longhofer, J., Barrett, T., Lawson, P., \& Floersch, J. (2006). Ethnographic approaches to child care research: A review of the literature. Journal of Early Childhood Research, 4(1), 45-63.

Catarsi, E., \& Fortunati, A. (2013). Educare al nido [Educating in nursery school]. Urbino, Italy: Carocci.

Cekaite, A. (2010). Shepherding the child: embodied directive sequences in parent-child interactions. Text and Talk, 30(1), 1-25.

Cekaite, A. (2015). Coordination of talk and touch in adult-child directives: Touch and social control. Research on Language and Social Interaction, 48, 152-175. https://doi.org/10.1080/08351813.2015.1025501.

Cekaite, A. (2016). Touch as social control: Haptic organization of attention in adult-child interaction. Journal of Pragmatics, 92, 30-42. https://doi.org/10.1016/j.pragma.2015.11.003.

Cekaite, A., \& Holm Kvist, M. (2017). The comforting touch: Tactile intimacy and talk in managing children's distress. Research in Language and Social Interaction, 50(2), 109-127.

Corsaro, W. A. (1997). The sociology of childhood. Pine Forge Press.

Craven, A., \& Potter, J. (2010). Directives: Entitlement and contingency in action. Discourse Studies, 12(4), 419442.

Curl, T., \& Drew, P. (2008). Contingency and action: A comparison of two forms of requesting. Research on Language and Social Interaction, 41(2), 129-153.

Dalton-Puffer, C., \& Nikula, T. (2006). Pragmatics of content-based instruction: Teacher and student directives in Finnish and Austrian classrooms. Applied Linguistics, 27(2), 241-267. https://doi.org/10.1093/applin/ aml007.

Depperman, A. (2013). Multimodal interaction from a conversation analytic perspective. Journal of Pragmatics, 46, 1-7. https://doi.org/10.1016/j.pragma.2012.11.014.

Duranti, A., Ochs, E., \& Schieffelin, B. (Eds.). (2012). The handbook of language socialization. Wiley Blackwell: Oxford.

Erving Tripp, S. (1976). Is Sybil there? The structure of some American English directives. Language in Society, $5,25-66$.

Fasulo, A., Loyd, H., \& Padiglione, V. (2007). Children's socialization into cleaning practices: A cross-cultural perspective. Discourse \& Society, 18, 11-33. 
Feinman, S. (1982). Social referencing in infancy. Merrill-Palmer Quarterly, 28, 445-470.

Flynn, V., \& Masur, E. F. (2007). Characteristics of maternal verbal style: Responsiveness and directiveness in two natural contexts. Journal of Child Language, 34(3), 519-543. https://doi.org/10.1017/ s030500090700801x.

Ford, C., Fox, B., \& Thompson, S. (1996). Practices in the construction of turns. Pragmatics, 6, 427-454.

Galeano, G., \& Fasulo, A. (2009). Sequenze direttive tra genitori e figli [Directive sequences between parents and children]. Etnografia e ricerca Qualitativa, 2, 261-278.

García-Carrión, R., \& Villardón-Gallego, L. (2016). Dialogue and interaction in early childhood education: A systematic review. REMIE -Multidisciplinary Journal of Educational Research, 6(1), 51-76. https://doi.org/ 10.17583/remie.2016.191.

Garfinkel, H. (1967). Studies in ethnomethodology. Englewood Cliffs, N.J.: Prentice-Hal.

Gernhardt, A., Lamm, B., Keller, H., \& Döge, P. (2014). Early child care teachers' socialization goals and preferred behavioral strategies: A cross-cultural comparison. Journal of Research in Childhood Education, 28(2), 203-220.

Girolametto, L., Weitzman, E., Lieshout, R., \& Duff, D. (2000). Directiveness in teachers' language input to toddlers and preschoolers in day care. Journal of Speech, Language and Hearing Research, 43, 1101-1114.

Goodwin, C. (1981). Conversational organization: Interaction between speakers and hearers. New York: Academic Press.

Goodwin, C. (2000). Action and embodiment within situated human interaction. Journal of Pragmatics, 32, 1489-1522.

Goodwin, M. H. (2006). Participation, affect, and trajectory in family directive/response sequences. Text and Talk, 26, 515-544. https://doi.org/10.1515/TEXT.2006.021.

Goodwin, M. H. (2015). A care-full look at language, gender and embodied intimacy. In A. Julé (Ed.), Shifting Visions: Gender and Discourses (pp. 27-48). Cambridge Scholars Publishing: Newcastle upon Tyne.

Goodwin, M. H. (2017). Haptic sociality: The embodied interactive construction of intimacy through touch. In C. Meyer et al. (Eds.), Intercorporeality: Beyond the body (pp. 73-102). Oxford, England: Oxford University Press.

Goodwin, M. H., \& Cekaite, A. (2013). Calibration in directive/response sequences in family interactions. Journal of Pragmatics, 46, 122-138. https://doi.org/10.1016/j.pragma.2012.07.008.

Goodwin, M. H., \& Cekaite, A. (2014). Orchestrating directive trajectories in communicative projects in family interaction. In P. Drew \& E. Couper-Kuhlen (Eds.), Requesting in Social Interaction (pp. 185-214). John Benjamins: Amsterdam / Philadelphia.

Goodwin, M. H., \& Cekaite, A. (2018). Embodied family choreography: Practices of control, care, and mundane creativity. London: Routledge.

Goodwin, M. H., \& Goodwin, C. (2000). Emotion within situated activity. In N. Budwig, I. Č. Užgiris, \& J. V. Wertsch (Eds.), Advances in applied developmental psychology. Communication: An arena of development (pp. 33-53). Ablex Publishing.

Harkness, S., Super, C. M., \& van Tijen, N. (2000). Individualism and the "western mind" reconsidered: American and Dutch parents' ethnotheories of the child. New Direction in Child and Adolescent Development, 87, 23-39. https://doi.org/10.1002/cd.23220008704.

Harmes, T., Cryere, D., \& Clifford, R. M. (1998). Early childhood environment rating scale (Revised ed.). New York: Teachers College Press.

He, A. W. (2000). The grammatical and interactional organization of teacher's directives: Implications for socialization of Chinese American children. Linguistics and Education, 11, 119-140.

Hepburn, A., \& Potter, J. (2011). Threats: power, family mealtimes, and social influence. British Journal of Social Psychology, 50(1), 99-120.

Holmes, J. (1983). The structure of teachers' directives. In J. C. Richards \& R. W. Schmidt (Eds.), Language and communication (pp. 89-115). London: Longman.

Howes, C. (1987). Social competence with peers in young children: Developmental sequences. Developmental Review, 7, 252-272.

Howes, C. (1988). Peer interaction of young children. Monographs of the Society for Research in Child Development, 53(1) Serial No. 217.

Iedema, R. (1996). Save the talk for after the listening: The realisation of regulative discourse in teacher talk. Language and Education, 10, 82-103.

Kent, A. (2011). Directing dinnertime: Practices and resources used by parents and children to deliver and respond to directive actions. $P h D$ thesis. Loughborough University.

Kidwell, M. (2012). Interaction among children. In J. Sidnell \& T. Stivers (Eds.), The handbook of conversation analysis (pp. 511-532). Wiley-Blackwell: Oxford, U.K. 
Kochanska, G., Forman, D., Aksan, N., \& Dunbar, S. (2005). Pathways to conscience: Early mother- child mutually responsive orientation and children's moral emotion, conduct, and cognition. Journal of Child Psychology and Psychiatry, 46, 19-34. https://doi.org/10.1111/j.1469-7610.2004.00348.x.

Lerner, G. H., \& Zimmerman, D. H. (2003). Action and the appearance of action in the conduct of very young children. In P. Glenn, J. Mandelbaum, \& C. LeBaron (Eds.), Studies in language and social interaction: In honor of Robert Hopper (pp. 441-457). Mahwah, NJ: Lawrence Erlbaum Associates, Inc..

Lerner, G. H., Zimmerman, D. H., \& Kidwell, M. (2011). Formal structures of practical tasks: A resource for action in the social life of very young children. In J. Streeck, C. LeBaron, \& C. Goodwin (Eds.), Embodied Interaction. Language and Body in the Material World (pp. 44-58). Cambridge: Cambridge University Press.

Majorano, M., Corsano, P., \& Triffoni, G. (2015). Educators' intervention, communication and peers' conflict in nurseries. Child Care in Practice, 21(2), 98-113. https://doi.org/10.1080/13575279.2014.1001812.

Mehus, S. (2011). Creating contexts for actions: multimodal practices for managing children's conduct in the childcare classroom. In J. Streeck, C. LeBaron, \& C. Goodwin (Eds.), Embodied Interaction. Language and Body in the Material World (pp. 123-136). Cambridge: Cambridge University Press.

Mercer, N., \& Howe, C. (2012). Explaining the dialogic processes of teaching and learning: The value and potential of sociocultural theory. Learning, Culture and Social Interaction, 1, 12-21. https://doi.org/10. 1016/j.icsi.2012.03.001.

Molinari, L., Cigala, A., Corsano, P., \& Venturelli, E. (2017). Observing children's triadic play. In T. Bruce, P. Hakkarainen, \& M. Bredikyte (Eds.), The Routledge international handbook series. The Routledge international handbook of early childhood play (pp. 216-229). Routledge/Taylor \& Francis Group.

Monaco, C. (2007) ZeroTre. Che cosa fanno I bambini al nido [ZeroThree. What children do in nursery school]. Infantiae.Org ${ }^{\mathrm{TM}}$

Mondada, L. (2016). Challenges of multimodality: Language and the body in social interaction. Journal of Sociolinguistics, 20, 336-366. https://doi.org/10.1111/josl.1_12177.

Musatti, T., \& Mayer, S. (2011). Sharing attention and activities among toddlers: The spatial dimension of the setting and the educator's role. European early childhood education research journal, 19, 201-220.

Musatti, T., \& Panni, S. (1981). Social behavior and interaction among daycare center toddlers. Early Child Development and Care, 7, 5-25.

Musatti, T., \& Picchio, M. C. (2010). Early education in Italy: Research and practice. International Journal of Early Childhood, 42, 141-153. https://doi.org/10.1007/s13158-010-0011-9.

Musatti, T., Mayer, S., Pettenati, P., \& Picchio, M. (2017). Toddlers' participation in joint activities with peers in nido. In E. J. White \& C. Dalli (Eds.), Under-three years old in policy and practice (pp. 73-86). Springer.

Ochs, E., \& Schieffelin, B. (1989). Language has a heart. Text, 9(1), 7-25.

Ochs, E., Pontecorvo, C., \& Fasulo, A. (1996). Socializing taste. Ethnos, 1(2), 7-46.

Oliveira, A. (2009). "Kindergarten, can I have your eyes and ears?" Politeness and teacher directive choices in inquiry-based science classrooms. Cultural Studies of Science Education, 4, 803-846. https://doi.org/10. 1007/s11422-009-9193-6.

Paugh, A., \& Izquierdo, C. (2009). Why is this a battle every night? Negotiating food and eating in American dinnertime interaction. Journal of Linguistic Anthropology, 19(2), 185-204.

Pauletto, F., \& Fatigante, M. (2015). 'Dai, da' na mano!' Tra il dire e il chiedere: l'uso del segnale discorsivo dai in conversazioni in famiglia. Rivista di Psicolinguistica Applicata, XV- 1, 89-103

Pauletto, F., Aronsson, K., \& Galeano, G. (2017). Endearment and address terms in family life: Children's and parents' requests in Italian and Swedish dinnertime interaction. Journal of Pragmatics, 109, 82-94.

Pianta, R., Howes, C., Burchinal, M., Bryant, D., Clifford, R., Early, D., \& Barbarin, O. (2005). Features of prekindergarten programs, classrooms, and teachers: Do they predict observed classroom quality and childteacher interactions? Applied Developmental Science, 9(3), 144-159. https://doi.org/10.1207/ s1532480xads0903 2.

Pianta, R. C., La Paro, K. M., \& Hamre, B. K. (2008). Classroom assessment scoring system -PreKmanual. Baltimore, MD: Brookes.

Psathas, G. (1995). Conversation analysis. New York: Sage Publication.

Reddy, V., Liebal, K., Hicks, K., Jonnalagadda, S., \& Chintalapuri, B. (2013). The emergent practice of infant compliance: An exploration in two cultures. Developmental Psychology, 49, 1754-1762. https://doi.org/10. 1037/a0030979.

Rojas-Drummond, S., Torreblanca, O., Pedraza, H., Vélez, M., \& Guzmán, K. (2013). 'Dialogic scaffolding': Enhancing learning and understanding in collaborative contexts. Learning, Culture and Social Interaction, 2, 11-21. https://doi.org/10.1016/j.lcsi.2012.12.003.

Sacks, H., Schegloff, E., \& Jefferson, G. (1974). A simplest systematics for the organisation of turn-taking in conversation. Language \& Communication, 50(4), 696-735. 
Sairanen, H., Kumpulainen, K., \& Kajamaa, A. (2020). An investigation into children's agency: children's initiatives and practitioners' responses in Finnish early childhood education. Early Child Development and Care. https://doi.org/10.1080/03004430.2020.1739030.

Schegloff, E. A. (2007). Sequence organization in interaction: a primer in conversation analysis. Cambridge: Cambridge University Press.

Schegloff, E. A., \& Sacks, H. (1973). Opening up closings. Semiotica, 8, 289-327.

Schieffelin, B., \& Ochs, E. (1984). Language acquisition and socialization: Three developmental stories and their implications. In R. Shweder \& R. Levine (Eds.), Culture Theory: Essays on Mind, Self and Emotion (pp. 276-320). Cambridge University Press.

Singer, E., \& de Haan, D. (2007). The social lives of young children : Play, conflict and moral learning in daycare groups. Amsterdam: SWP.

Singer, E., Nederend, M., Penninx, L., Mehrnaz, T., \& Boom, J. (2014). The educator's role in supporting young children's level of play engagement. Early Child Development and Care, 184(8), 1233-1249. https://doi. org/10.1080/03004430.2013.862530.

Smidt, W. \& Lehrl, S. (2020) Teacher-child interactions in early childhood education and care classrooms. Characteristics, predictivity, dependency and methodological issues. Routledge

Sterponi, L. (2009). Accountability in family discourse. Childhood, 16, 441-459. https://doi.org/10.1177/ 0907568209343269 .

Stivers, T., \& Sidnell, J. (Eds.). (2013). The Handbook of Conversation Analysis. Oxford, U.K.: WileyBlackwell.

Streeck, C., LeBaron, C., \& Goodwin, C. (Eds.). (2011). Embodied interaction. Language and body in the material world. Cambridge: Cambridge University Press.

Tobin, J., Wu, D., \& Davidson, D. (1989). Preschool in three cultures: Japan, China, and the United States. New Haven, CT: Yale University Press.

Tulbert, E., \& Goodwin, M. H. (2011). Choreographies of attention: Multimodality in a routine family activity. In J. Streeck, C. LeBaron, \& C. Goodwin (Eds.), Embodied interaction. Language and Body in the Material World (pp. 79-92). Cambridge: Cambridge University Press.

Ulferts, H., Wolf, K. M., \& Anders, Y. (2019). Impact of process quality in early childhood education and care on academic outcomes: Longitudinal meta-analysis. Child Development, 90(5), 1474-1489. https://doi.org/ 10.1111/cdev.13296.

Vygotsky, L. (1978). Mind in society: The development of higher psychological processes. Cambridge, MA: Harvard University Press.

White, E. J., \& Dalli, C. (Eds.). (2017). Under-three years old in policy and practice. Springer Books.

White, E. J., Peter, M., \& Redder, B. (2015). Infant and teacher dialogue in education and care: A pedagogical imperative. Early Childhood Research Quarterly, 30, 160-173. https://doi.org/10.1016/j.ecresq.2014.10. 008.

Whitebread, D. (2012). Developmental psychology and early childhood education. London: Sage.

Whitebread, D., Basilio, M., Kuvalja, M., \& Verma, M. (2012). The importance of play. Brussels, Belgium: Toys Industries for Europe.

Publisher's note Springer Nature remains neutral with regard to jurisdictional claims in published maps and institutional affiliations.

Marilena Fatigante. Department of Social and Developmental Psychology, Sapienza University of Rome, via dei Marsi 78, Rome, Italy. Email: marilena.fatigante@uniroma1.it

Current themes of research:

1. Study of social interaction in natural settings

2. Ethnography and video analysis

3. Conversation analysis of institutional interaction (such as, classroom interaction, interaction in healthcare setting)

4. Self-narratives

5. Identity categorization in interviews

6. Intercultural communication

7. Ethics in research and reflexivity

8. Situated methods for social psychology). 
9. Socialization practices in early years

Most relevant publications in the field of Psychology of Education:

1. Buonomo, I., Fatigante, M., Fiorilli, C. (2017) Teachers' burnout profile: risk and protective factors. The Open Psychology Journal , 10, 190-201. DOI: https://doi.org/10.2174/1874350101710010190

2. Sterponi, L. , Zucchermaglio, C., Alby, F., Fatigante, M. (2017) Endangered literacies? Affordances of paperbased literacy in medical practice and its persistence in the transition to digital technology. Written Communication, 34, 4, 359-386. DOI: 10.1177/0741088317723304

3 Kremer-Sadlik, T., Izquierdo, C., Fatigante, M. (2010) Making meaning of everyday practices: parents' attitudes toward children's extra-curricular activities in the United States and in Italy. Anthropology \& Education Quarterly, Vol. 41, Issue 1, pp.35-54, ISSN 0161-7761. DOI:10.1111/j.15481492.2010.01066.x.

4. Alby, F., Fatigante, M., Zucchermaglio, C. (2017) "It may also be the case that you say I don't want to do it". Imaginary scenarios as resources to argue for treatment advice in cancer consultations. In Arcidiacono and Bova (Eds.) "Interpersonal Argumentation in Educational and Professional Contexts", Springer

5. Fatigante, M., Bafaro, S., Orsolini, M. (2015) 'And you? What do you think then?' Taking care of thought and reasoning in intellectual disability. In M. O'Reilly, J.N. Lester (eds) The Palgrave Handbook of Child Mental Palgrave Macmillan UK. Health, 597-617. DOI: 10.1007/978-1-137-42831-8_32. (Print) ISBN: 978-1-349-57695-1, (online) ISBN: 978-1-137-42831-8.

6. Fatigante, M (2011) Resoconto e narrazione nei colloqui di consultazione con bambino e genitori (tr. Reporting and narrating in psychodiagnostic interviews with parents and children). In M. Orsolini (ed) Quando imparare è più difficile. Dalla valutazione all'intervento. Roma: Carocci, 273-294. ISBN: 8874666128

7. Orletti, F., Fatigante, M. (2005) La costruzione discorsiva di bambini con difficoltà di apprendimento. (tr. The discoursive construction of children with learning disabilities.) In C.Pontecorvo (ed) Discorso e Apprendimento. Roma: Carocci, 61-72193-204. ISBN 8876673687, 9788876673689.

8. Fatigante, M., Orletti, F. (2005) Integrazione della disabilità e partecipazione al discorso in classe (tr. Inclusion of disability and child participation to classroom discourse). Infantiae.Org ${ }^{\mathrm{TM}}$ n.238/2005 [http://www. infantiae.org/DAPorlettifatigante.asp]

9. Orletti, F., Fatigante, M. (2005) L'insegnante e il bambino con difficoltà. (tr. The teacher and the child with disabiliy). In CD-rom DAP (Discorso e Apprendimento) per l'autoformazione degli insegnanti. Roma: Edizioni Infantiae.Org

Lilia Antici. Sapienza University of Rome, Rome, Italy. Email: lilia.antici@gmail.com

'No previous publications'.

Cristina Zucchermaglio. Department of Social and Developmental Psychology, Sapienza University of Rome, via dei Marsi 78, Rome, Italy. Email: cristina.zucchermaglio@uniroma1.it

\section{Current themes of research:}

1) Communication, reasoning and decision making in oncology

Studies focus on oncologists' diagnostic reasoning practices, communication with patients ,medical education paths

2) Youth "navigation paths" from university to the labor market

Qualitative and quantitative analyses of the heterogeneous and dynamic characteristics of the "navigations" of young graduates' in their transition to the workplace.

3) Cognition-in-interaction

Ecological studies of the social organization of cognition in everyday and learning settings.

4) Groups at work and workplaces studies

Analyses of groups as communities of practice, social action and interaction, collaboration, shared meaning making, collective decision making processes.

5) Families and organizing Studies of dual career families and practices of managing 'busy' family lives.

6) Situated research methods and reflexivity

Studies of the researched-researcher relationship and its influence on the research process and data; research on situated methods : ethnography and multimodal analysis of interaction and practices 
1) Zucchermaglio, C., Pontecorvo, C., Tonucci, F., Blachowicz, C. (1986). Linguistic awareness and literacy. Reading Psychology, 1 (7), 11-25

2) Ajello, A.M., Bombi, A.S., Pontecorvo, C., Zucchermaglio, C. (1987). Teaching economics in the primary school: The concept of work and profit. International Journal of Behavioral Development, 10, (1), 51-69 (IF: 1, 993)

3) Ajello, A.M., Bombi, A.S., Pontecorvo, C., Zucchermaglio, C. (1986). Children's understanding of Agriculture as an Economic Activity: The role of figurative information. European Journal of Psychology of Education, 1,(3), 198, 67-80 (IF: 1, 483)

4) Pontecorvo, C., Zucchermaglio, C. (1988). Modes of differentiation in children's writing construction. European Journal of Psychology of Education. III,4, 371-384 (IF: 1,483)

5) Pontecorvo, C., Orsolini, M., Zucchermaglio, C. (1989). Metalinguistic skills in children: What develops?. Infancia Y Aprendizaje. 47. 37-54

6) Pontecorvo, C., Zucchermaglio, C. (1989). From oral to written language: Preschool children dictating stories. Journal of Reading Behavior. vol.XXI, N.2, 109-126

7) Blachowicz, C.L.Z., Zucchermaglio, C. (1989) Literacy instruction in Italy. The Reading Teacher. vol. 43, n. $1,38-41$

8) Zucchermaglio, C. (1989) Literacy development through social interaction. Dossier de Psychologie. N.37, 4752

9) Pontecorvo, C., Zucchermaglio, C. (1991).Computer's use in language education. European Journal of Psychology of Education., vol. VI, N.1, 15-27 (IF: 1, 483)

10) Zucchermaglio, C, Alby, F. (2013) "It seems that things take care of themselves": Routines as resources for the management of busy family life. Mind, culture and activity, 21,(1), 21-33 (IF: 1,180)

11) Ajello, A.M., Bombi, A.S., Zucchermaglio, C. (1985) Teaching economics in the primary school: content and method. In D. Whithead (Ed.), Economics education: Research and development issues (pp. 113-126). London: Longman.

12) Zucchermaglio, C., Pontecorvo, C. (1989). Learning text composition in early literacy. In H. Mandl, E. De Corte, S.N. Bennet \& H.F. Friedrich (Eds.). Learning and instruction: European research in an international context .vol.II, III Oxford: Pergamon

13) Pontecorvo, C., Zucchermaglio, C. (1990). A passage to literacy: Learning in a social context. In Y. Goodman (Ed.), How children construct literacy. Newark, Del :International Reading Association.

14) Zucchernaglio, C. (1992) Toward a cognitive ergonomics of educational technology. In T. Duffy, J. Lowick D. Jonassen (Editors), The design of constructivist learning environments: Implications for instructional design and the use of technology. Springer Verlag, New York

15) Ferreiro, E. Pontecorvo, C. Zucchermaglio, C. (1995) PIZZA or PIZA? How children interpret the doubling of letters in writing. In C. Pontecorvo, M. Orsolini, B. Burge, L. Resnick (Eds). The child construction of text. New York: Lawrence Erlbaum Associates

16) Ferreiro, E. \& Zucchermaglio, C. (1995) Children's use of punctuation marks: The case of "quoted speech". In C. Pontecorvo, M. Orsolini, B.Burge, L. Resnick (Eds). The child construction of text. New York: Lawrence Erlbaum Associates

17) Zucchermaglio, C. (1995). Organizational and cognitive design of the (technological) learning environment. In Zucchermaglio, C., Bagnara, S. \& Stucky, S. (Eds.). Organizational learning and technological change. New York: Springer Verlag

18) Zucchermaglio, C. (1995) Technology for cooperative learning and working In Zucchermaglio, C., Bagnara, S. \& Stucky, S. (Eds.). Organizational learning and technological change. New York: Springer Verlag

19) Zucchermaglio, C., Scaratti, G. Ferrai, L. (2012) Apprendere-trasformando: costruire e abitare le proprie pratiche lavorative. (tr. Learning -changing: Constructing and inhabiting one own's work practices) Scuola Democratica, 4, 77-92

20) Zucchermaglio, C. (1991). Gli apprendisti della lingua scritta. (tr. The apprentices of written language) Bologna: Il Mulino

21) Pontecorvo, C., Ajello, A.M., Zucchermaglio, C. (1991). Discutendo si impara. Roma: La Nuova Italia Scientifica (trad. portoghese Pontecorvo, C., Ajello, M. A. M., \& Zucchermaglio, C. (2005). Discutindo se aprende: interação social, conhecimento e escola. Porto Alegre: Artmed.)

22) Zucchermaglio, C. (1996). Vygotsky in azienda. Apprendimento e comunicazione nei contesti di lavoro. (tr. Vygotsky in the firm. Learning and communication in workplace contexts). Roma: La Nuova Italia Scientifica

23) Pontecorvo, C., Ajello, A.M., Zucchermaglio, C.(Eds.) (1995). I contesti sociali dell'apprendimento. (tr. Social contexts of learning). Milano: Zanichelli 
Valentina Fantasia. Department of Social and Developmental Psychology, Sapienza University of Rome, via dei Marsi 78, Rome, Italy. Email: valentina.fantasia@uniroma1.it

Current themes of research:

Most relevant publications in the field of Psychology of Education:

1. Fantasia, V., C., Markant, D.B., Perry, N., Valeri G., Ruggeri, A. (Accepted). Memory enhancements from active control of learning emerge across development in children with Autism Spectrum Disorders. Autism

Francesca Alby. Department of Social and Developmental Psychology, Sapienza University of Rome, via dei Marsi 78, Rome, Italy. Email: francesca.alby@uniroma1.it

Current themes of research:

1. Groups at work and workplaces studies- communities of practice

2. Technology and its socio-cognitive 'mediation'

3. Cognition-in-interaction ('ecological' studies of the social organization of cognition in everyday settings)

4. Communication in oncology

5. Situated research methods and reflexivity (studies of the researched-researcher relationship and its influence on the research process and data; research on situated methods for social psychology).

Most relevant publications in the field of Psychology of Education:

1. Relucenti, M., Alby, F., Longo, F., Miglietta, S., Fatigante, M., Familiari, P., Zucchermaglio, C., \& Familiari, G. (2019). Social media Facebook and You Tube usefulness in anatomy learning: experience at Sapienza University of Rome. Italian Journal of Anatomy and Embryology, 124(2), 216-229.

2. Sterponi L., Zucchermaglio C., Alby F., Fatigante M. (2017) Endangered literacies:What is lost in the transition to digital literacy technology in medical practice? Written communication.An International Quarterly of Research, Theory, and Application, Vol. 34(4) 359-386. https://doi.org/10.1177/ 0741088317723304 (Impact Factor 2017: JCR 1.267; Citescore based on ScopusAONgVuLUz9U3MCq2NLNYxMoWnJxfUFoMAB7g8p0WAAAA\&sa=X\&ved= 2ahUKEwiM6PKDoYLlAhWQC-wKHWSoDFsQmxMoAjAZegQICRAI"/> 1.94; Numero medio di citazioni per anno: 0.33 )

3. Zucchermaglio C., Alby F. (2016) Theorizing about practice: storytelling and practical knowledge in cancer diagnoses. Journal of Workplace Learning, 28, 4, pp. 174-187. doi:10.1108/JWL-01-2016-0006 Impact factor 2016: CitescoreAONgVuLVT9c3NMwwN8wozzG0XMTK6ZxZk1qcnFU C g D w e 6 Y 2 H Q A A A \& s a = X \& v ed=2 a h U E w i M 6 P K D o Y L 1 A h W Q C w K H W S o D F s Q m x M o A T A Z e g Q I R A H " / > b a s e d o n ScopusAONgVuLUz9U3MCq2NLNYxMoWnJxfUFoMAB7g8p0WAAAA\&sa=X\&ved= 2ahUKEwiM6PKDoYL1AhWQC-wKHWSoDFsQmxMoAjAZegQICRAI"/> 1.2; Numero medio di citazioni per anno: 0.25 )

4. Zucchermaglio , C. , Alby, F. (2009) Learning to work or working to learn? A university-work transition case study. Learning Inquiry, 3:79-95 (indexed in Scopus)

5. Zucchermaglio , C., Alby, F. (2005) Some reflections on learning and E-learning, PsychNology Journal, vol. 3 (2), 200-222 (indexed in Scopus)

6. Alby F., Zucchermaglio C. (2008) La realizzazione interattiva di un modello formativo in rete: quando allontanarsi dal modello didattico non è un difetto. (tr. The interactive accomplishment of a formative model online: When departing from didactic model is not a failure). Psicologia dell'educazione, n.3, pp. 413-428

7. Alby F. (2004) Come si impara on-line? I modelli didattici nell'e-learning. (tr. How do we learn on line? Didactic models in elearning) FOR Rivista per la formazione, n.58, 76-84

8. Bertini G., Alby F., Bertini G.B. (2001) Self-managed learning paths in health care, Kanbrain, n.0 November, 52-67

9. Zucchermaglio C., Alby, F. (2000) Imparare volando: pratiche di lavoro e socializzazione organizzativa. (tr. Learning by flying: Work practices and organizational socialization). Scuola Democratica, n. 1/2, gennaio/ giugno, pp. 219-234

10. Alby F., Bertini, G. (1999) L'intervento organizzativo autogestito. Sviluppi e applicazioni dell'Audit dell'apprendimento organizzativo.(tr. The self-managed organizational intervention. Developments and 
applications of the audit in organizational learning). Sviluppo \& Organizzazione, n.173, maggio/giugno, 3146

11. Zucchermaglio C., Alby, F., (1999) Le storie come strumento di indagine della socializzazione organizzativa. (tr. Narratives as research tools of organizational socialization). Bollettino di Psicologia Applicata, vol. 229, 47-51

12. Alby F. (1999) Le rappresentazioni narrative come metodo di sviluppo delle comunità. (tr. Narrative representations as method for community development). Sistemi \& Impresa, gennaio-febbraio, 31-41

13. Tomassini M., Alby, F. (1998) Reti di apprendimento di piccole e medie imprese. Nuove prospettive per la formazione. (tr. Learning networks in small and medium firms. New perspectives for education). Scuola Democratica, n. 1-2, gennaio/giugno, 287-307

14. Alby F., Mora F. (2004), Il bilancio di competenze. Conoscere se stessi e capire le organizzazioni. (tr. Competence balance. Knowing oneself and understanding organizations). Roma: Carocci

15. Frigo F., Alby F. (Eds.) (2004) La qualità dell'e-learning nella Formazione Continua. (tr. The quality of elearning in life long education). Soveria Mannelli (CZ): Rubbettino Editore

16. Zucchermaglio C., Alby, F. (2006) “Apprendere on-line: dal ‘trasferimento' alla partecipazione alle comunità virtuali”. (tr. Learning online : from transfer to participation in virtual communities). In A. Talamo e S. Pozzi (Eds.) Formazione a distanza e innovazione psicosociale (pp. 15-41). Napoli: Scriptaweb

17. Zucchermaglio C., Alby F.(2006) "I confini tra comunità come luogo di apprendimento organizzativo". (tr. Community boundaries as places for organizational learning). In C. Zucchermaglio e F. Alby (Eds.) Psicologia Culturale delle Organizzazioni (pp. 181-200). Roma: Carocci

18. Alby F. (2004) Perché il tema della qualità nell'e-learning? (tr The topic of quality in the e-learning) In F. Frigo e F. Alby (Eds.) (2004) La qualità dell'e-learning nella Formazione Continua (pp.27-28). Soveria Mannelli (CZ): Rubbettino Editore

19. Alby F. (2004) E-learning e apprendimento. (tr. E-learning and learning processes). In F. Frigo \& F. Alby (Eds.) (2004) La qualità dell'e-learning nella Formazione Continua (pp.49-56). Soveria Mannelli (CZ): Rubbettino Editore

20. Alby F. (2003) Come si impara on-line?: una classificazione 'educativa' della formazione in rete. (tr. How online learning develops?: an educational categorization of online learning). In F. Frigo e P. Richini (a cura di) I Laboratori della Formazione Continua (pp.237-252). Milano: Franco Angeli

\section{Affiliations}

\section{Marilena Fatigante ${ }^{1} \cdot$ Lilia Antici $^{2} \cdot$ Cristina Zucchermaglio $^{1} \cdot$ Valentina Fantasia $^{1}$. Francesca Alby ${ }^{1}$}

1 Department of Social and Developmental Psychology, Sapienza University of Rome, via dei Marsi, 78 Rome, Italy

2 Sapienza University of Rome, Rome, Italy 